\title{
Greenhouse Gas Emissions from Heavy-duty Natural Gas Vehicles in Korea
}

\author{
Jigu Seo ${ }^{1}$, Seokjoo Kwon ${ }^{2}$, Sungwook Park ${ }^{3 *}$ \\ ${ }^{1}$ Graduate School of Hanyang University, Seoul 04763, Korea \\ ${ }^{2}$ Korea Automotive Technology Institute, Chungnam 31214, Korea \\ ${ }^{3}$ School of Mechanical Engineering, Hanyang University, Seoul 04763, Korea
}

\begin{abstract}
Since 1991, heavy-duty natural gas vehicles (NGVs) have been supplied as an alternative to heavy-duty diesel vehicles (HDVs) in Korea. This study calculated the emissions from 40 compressed natural gas (CNG) buses by using a backwardlooking vehicle simulation model; based on these results, the total heavy-duty NGV GHG emissions in the country were estimated to be 1.66 million tons annually, which contributes $6.75 \%$ of the total national GHG emissions from HDVs. Compared to diesel HDVs in a similar weight class, heavy-duty NGVs emit $6.3 \%$ less GHG_or 39.3 tons less per vehicle annually-on average.
\end{abstract}

Keywords: Greenhouse gas reduction; Alternative fuel; Simulation method; Tank to wheel.

\section{INTRODUCTION}

Over the last few decades, there have been many efforts to address greenhouse gas (GHG) emissions in the transportation sector, which is responsible for $14 \%$ of global GHG emissions (IPCC, 2014). Many countries have set GHG reduction targets, and various policies have been implemented. The European Union set a target of reducing domestic GHG emissions by 40\% compared to 1990 levels. In Korea, the government plans to reduce transportation GHG emissions by $29.3 \%$ below business-as-usual levels by 2030 (ME, 2018).

The GHG regulations of vehicles were introduced to reduce GHG emissions from the transportation sector, and the standards have progressed significantly over the past few decades. In the past, GHG regulations have been imposed mainly on light-duty vehicles (LDVs). Nearly $80 \%$ of the light-duty vehicles in the world are subject to GHG regulations (Yang and Bandivadekar, 2017). However, as the global demand for $\mathrm{GHG}$ reduction continues to grow, GHG reduction from LDVs is not enough, and GHG reduction from heavyduty vehicles (HDVs) is becoming increasingly important. In the EU, GHG emissions from HDVs account for $25 \%$ of those from the transportation sector and this is about $6 \%$ of total EU GHG emissions (Mock, 2019). Similarly, in the U.S., HDVs emit $23 \%$ of transportation GHG emissions, which is $6 \%$ of U.S. GHG emissions (Sharpe and Muncrief, 2015).

\footnotetext{
* Corresponding author.

Tel: +82-2-2220-0430; Fax: +82-2-2220-4588

E-mail address: parks@hanyang.ac.kr
}

To reduce greenhouse gas emissions, many technologies have been applied to HDVs, and replacing conventional diesel vehicles with NGVs is one of the effective ways for GHG reductions. Among the various alternative fuels for transportation such as liquefied petroleum gas (LPG), propane, hydrogen and fuel cells, natural gas has been considered one of the most feasible options for HDVs. The advantages of natural gas as an alternative fuel are its wide availability, eco-friendliness, compatibility with conventional engines and low cost (Agarwal et al., 2015; Khan et al., 2015). As the technology has improved, NGVs have become more efficient and cleaner than diesel vehicles. Literature shows that GHG, $\mathrm{NO}_{x}$ and $\mathrm{PM}$ emissions of $\mathrm{NGVs}$ are lower than those of diesel vehicles under real-world driving conditions (Engerer and Horn, 2010; Thiruvengadam et al., 2018). In the global transportation sector, 102 Mtoe natural gas is consumed, which is about $4 \%$ of the total energy consumption by the transportation sector. As GHG reduction is an important issue in the transportation sector, many studies have focused on GHG emission from heavy-duty NGVs.

Natural gas mainly consists of methane $\left(\mathrm{CH}_{4}\right)$, which has a higher hydrogen-to-carbon ratio than diesel fuel or gasoline fuel. Due to the lower hydrogen-to-carbon ratio, carbon dioxide $\left(\mathrm{CO}_{2}\right)$ emissions from natural gas are lower than those of other fuels (Khan et al., 2015). Some studies have found that compressed natural gas $(\mathrm{CNG})$ engines emit $20 \%$ less $\mathrm{CO}_{2}$ than gasoline vehicles at an equivalent level of work performance (Cho and He, 2007). Watabe et al. (2019) examined the GHG reduction impact of low-carbon vehicles such as battery electric vehicles, hydrogen fuel cell vehicles and natural gas vehicles. The result show that $\mathrm{CO}_{2-}$ equivalent $\left(\mathrm{CO}_{2}-\mathrm{eq}\right)$ emissions of $\mathrm{CNG}$ trucks are lower than 
those of diesel trucks regarding neutral-grade highway driving, but the difference in $\mathrm{CO}_{2}$-eq emissions between $\mathrm{CNG}$ trucks and diesel trucks depends on the driving pattern. Lajevardi et al. (2018) analyzed $\mathrm{CO}_{2}$ emissions and technological reduction potentials from diesel trucks and $\mathrm{CNG}$ trucks. The results show that $\mathrm{CNG}$ trucks emit $15 \%$ less $\mathrm{CO}_{2}$ than diesel trucks. The technological reduction potential of $\mathrm{CNG}$ trucks is $28-35 \%$ in the near future and $41-51 \%$ in the longer term, both of which are about $10 \%$ higher than the reduction potential values of diesel trucks. Graham et al. (2008) analyzed HDV GHG emissions from a variety of fuel types, including $\mathrm{CNG}$, hydrogen-enriched $\mathrm{CNG}$ (HCNG), liquefied natural gas (LNG), diesel and biodiesel. The tailpipe GHG emissions from CNG and HCNG HDVs are 10-20\% lower than those of diesel vehicles, but the GHG emissions of biodiesel HDVs are similar to those of diesel HDVs.

Although many studies have analyzed the GHG emission characteristics of individual heavy-duty NGVs, little attention has been paid to quantitative analysis of GHG emissions and reduction effects from heavy-duty $\mathrm{NGVs}$ on a macroscopic level. In this paper, we estimated total GHG emissions from heavy-duty NGVs and their GHG reduction effect compared to diesel HDVs in Korea. Simulation method was used to calculate GHG emission of 40 cases of heavy-duty NGVs, and statistical data were used to estimate total GHG emissions. The simulation model used in this paper was developed by the Korean Ministry of Environment to calculated $\mathrm{CO}_{2}$ emissions from HDVs. In addition to GHG emissions, energy efficiency analysis based on the lower heating values of natural gas and diesel was conducted.

\section{Heavy-Duty Natural Gas Vehicles in Korea}

In Korea, most of NGVs are CNG buses. Fig. 1 shows the 2017 distribution of CNG buses in Korea. CNG HDVs are classified into two types: heavy-HDV and light-HDV. Buses that are more than 9 meters in length or have a more than 36 passenger capacity are classified as heavy-HDV buses. The rest of buses are classified as light-HDV buses, passenger capacity of which are between 15 and 36 and the length is shorter than 9 meters. Most CNG buses are heavy-HDV city buses. The number of CNG HDVs in Korea is 26,651, and CNG HDVs account for $2.4 \%$ of all HDVs. According to Korean vehicle statistics (KAMA, 2018), 1.1 million HDVs were registered in $2017,82.5 \%$ of which were used for freight transport and $17.5 \%$ were used for passenger transport.

Table 1 shows the daily vehicle miles travelled (VMT) of HDVs from a national statistical database (TS, 2018). VMT data are measured annually in mandatory vehicle inspections and analyzed by the Korea Transportation Safety Authority. There are 1817 inspection centers in Korea that carry out mandatory vehicle inspections. The daily VMT of a CNG heavy-duty (HD) bus is $242.7 \mathrm{~km}$, which is much greater than that of a diesel HD bus; the daily VMT of a diesel heavy-HD bus is $193.1 \mathrm{~km}$, and that of a diesel light-HD bus is $45 \mathrm{~km}$. The CNG VMT is greater than the diesel VMT because most CNG HD buses are used for public transportation; generally public transportation vehicles have greater VMT than private vehicles.

\section{METHODOLOGY}

\section{Simulation Method}

In this paper, a simulation method was used to calculate $\mathrm{CO}_{2}$ emissions from CNG HDVs. In contrast to the chassis dynamometer test that is used in $\mathrm{CO}_{2}$ and fuel economy certification of LDVs, simulations are used to certify $\mathrm{CO}_{2}$ emissions from HDVs in many countries, including the U.S., EU and Japan. These countries developed simulation models for certification of $\mathrm{HDV} \mathrm{CO}_{2}$ emissions.

The EU developed an HDV simulation model called VECTO and simulation results are used for $\mathrm{HDV} \mathrm{CO}_{2}$ certification (Rodríguez, 2018). VECTO calculates vehicle $\mathrm{CO}_{2}$ emissions using a backward-looking model structure.

Table 1. Vehicle miles travelled statistics.

\begin{tabular}{ll}
\hline Type & Daily vehicle miles travelled \\
\hline Diesel light-HD bus & $45 \mathrm{~km}$ \\
Diesel heavy-HD bus & $193.1 \mathrm{~km}$ \\
CNG HD bus & $242.7 \mathrm{~km}$ \\
\hline
\end{tabular}

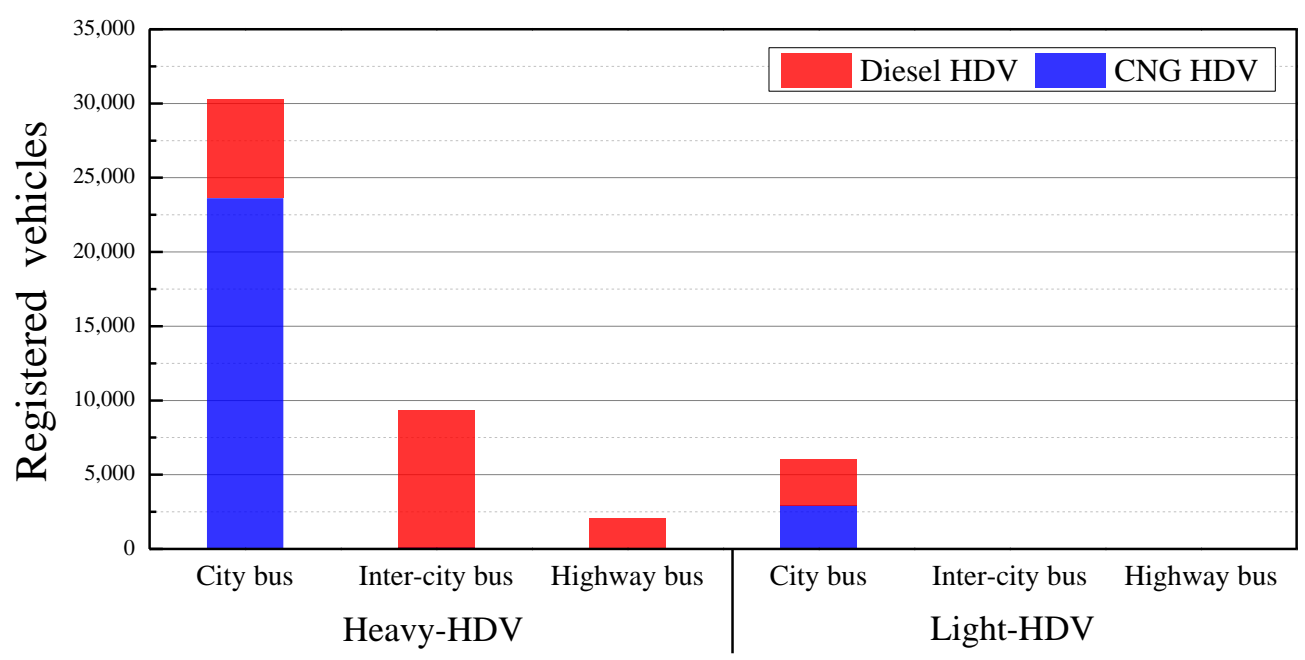

Fig. 1. Numbers of registered CNG and diesel heavy-duty and light-duty vehicles in Korea. 
The backward-looking model calculates the engine operating point from driving cycle and vehicle specifications. The driving cycle defines the vehicle target velocity and road gradient. This information is converted into engine demand torque and engine demand speed, taking into account vehicle specifications such as vehicle weight, air drag coefficient, rolling resistance coefficient and gear ratio. Calculated engine operating points are converted into fuel consumption and $\mathrm{CO}_{2}$ emissions by reading from an engine fuel consumption map.

This calculation process is known as "backward-looking" because the direction of this calculation flow is wheel to engine, which is opposite to the direction of actual energy flow. In real-world vehicle operation, the driver controls the engine power through the accelerator pedal. The engine power is transmitted to the wheels through the transmission to move the vehicle.

The U.S. HDV simulation model for $\mathrm{CO}_{2}$ certification of HDVs, which is called GEM, has a "forward-looking" architecture (Rodríguez, 2018). In forward-looking simulation model, calculation flow is engine to wheel. Based on the driver's demands, GEM estimate the required engine power to meet target velocity. If the vehicle speed is not sufficient to follow the target velocity, the driver module requests that more power be produced through feedback loop control algorithms. The advantage of the backward-looking model compared to the forward-looking model is the simplified model structure, as feedback loop power control is not essential for the backward-looking model. However, since the energy flow of the forward-looking model is similar to that of a real vehicle, the forward-looking model effectively reflects real vehicle behavior such as the driver's acceleration and deceleration style.

\section{Simulation Model Architecture}

In this paper, we used a simulation model that was developed to calculate the GHG emissions of Korean HDVs (Seo et al., 2018). This simulation model, called the Heavyduty Vehicle Emission Simulator (HES), was developed by the Ministry of Environment. The simulation architecture of HES is backward-looking as shown in Fig. 2. In the simulation calculation, the vehicle follows the predefined driving cycle K-WHVC. K-WHVC was developed to represent Korean HDV driving patterns based on real vehicle velocity and acceleration data measured from GPS tracking devices (Park et al., 2013), and K-WHVC is reference driving cycle for $\mathrm{CO}_{2}$ certification of HDVs in Korea. Fig. 3 shows a KWHVC driving cycle composed of an urban phase, rural phase and motorway phase. Each phase of the driving cycle represents a different driving pattern such as city driving and motorway driving.

The simulation model consists of four sub-modules: a vehicle module, a wheel module, an axle and transmission module and an engine module. In the vehicle module, the vehicle driving force is calculated based on input data such as the driving cycle, air drag coefficient, rolling resistance coefficient, vehicle weight and other vehicle specifications. In each time step, the total driving force is the sum of acceleration force, air drag force and rolling resistance force, as shown in the equation below:

$F_{\text {driving }}=F_{\text {accel }}+F_{\text {incl }}+F_{\text {air }}+F_{R R}$

where $F_{\text {driving }}$ is the total driving force $(\mathrm{N}), F_{\text {accel }}$ is the acceleration force $(\mathrm{N}), F_{\text {incl }}$ is the inclination force $(\mathrm{N}), F_{\text {air }}$ is the aerodynamic drag force $(\mathrm{N})$, and $F_{R R}$ is the rolling resistance force $(\mathrm{N})$.

The driving force, which is the result of the vehicle module, is then used as input data for the wheel module. In the wheel module, wheel torque and wheel speed are calculated using driving force, driving speed and wheel radius. Then, wheel speed and wheel torque are sent to the axle and transmission module.

In the axle and transmission module, gear shifting and torque loss are considered. Gear shifting is determined by surplus engine torque. Depending on the current engine speed and engine torque, the transmission module determines the gear position of every time step. A predefined gear shifting profile, which consists of an upshifting curve and a downshifting curve, is used as criteria for shifting. In addition to gear shifting, torque loss is considered when torque is

\section{Backward-looking Calculation flow}

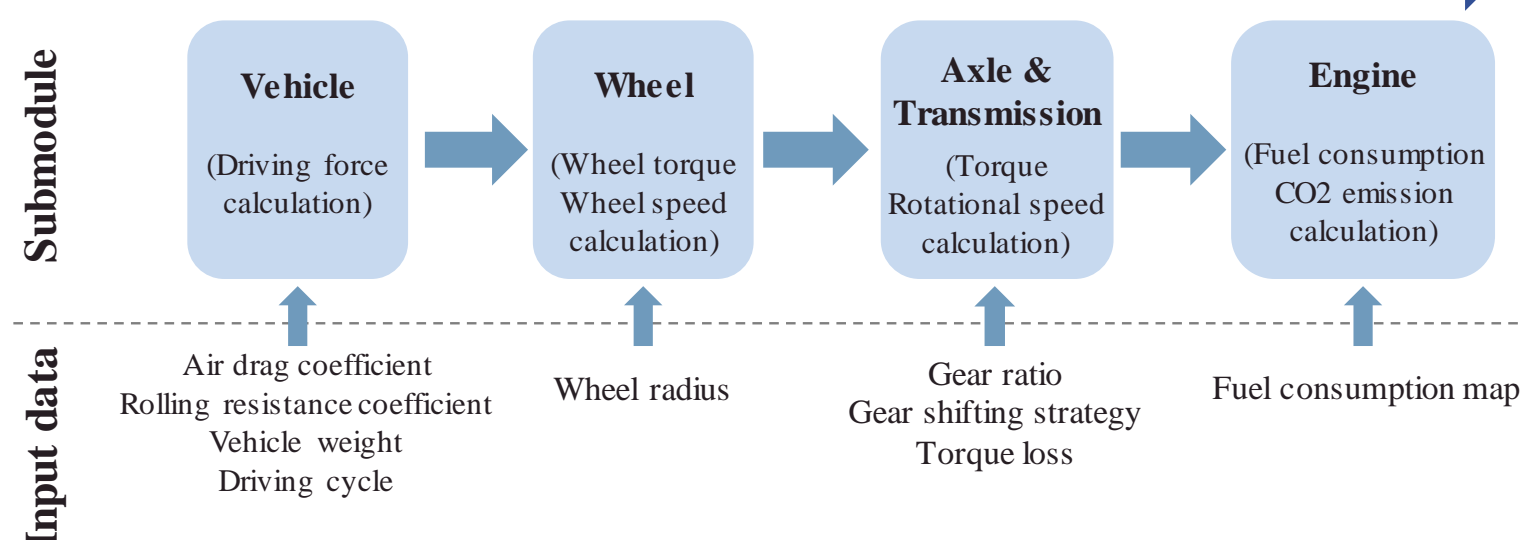

Fig. 2. Simulation model architecture. 


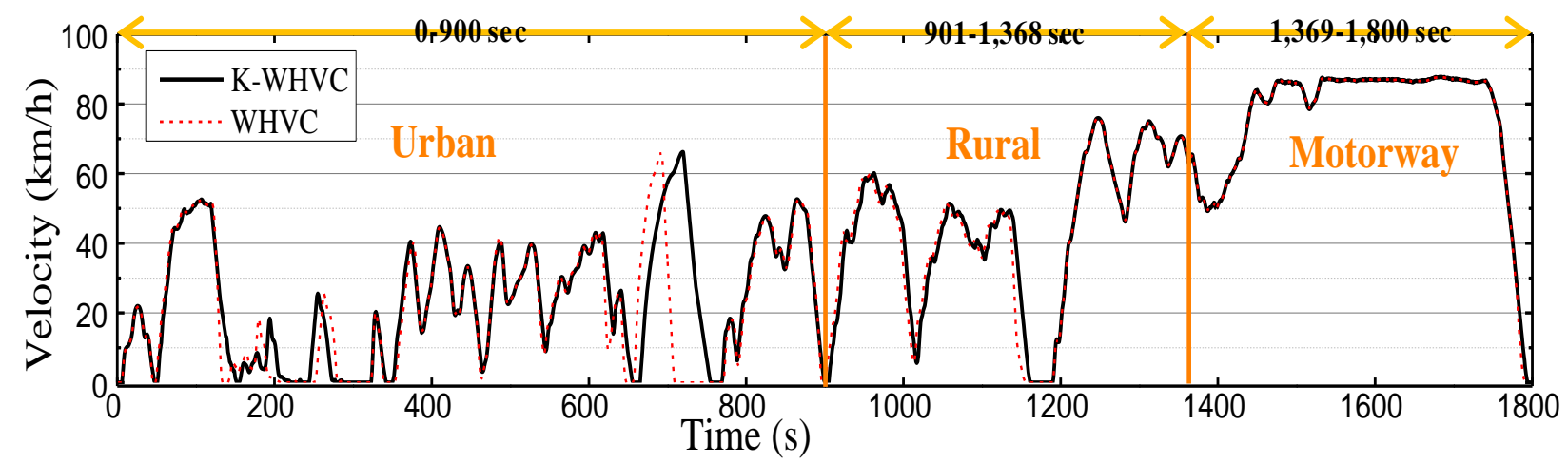

Fig. 3. WHVC and K-WHVC driving cycles.

transmitted through the transmission and axle gear. To calculate torque loss, torque loss map is used as input data for simulation model. The torque loss map defines torque loss according to input torque and the rotational speed of the gear. For automatic transmissions vehicle which is using fluid coupling, another torque loss is considered. In the simulation model, it is assumed that automatic transmission vehicles have $5 \%$ torque loss in fluid coupling. Finally, calculated torque and rotational speed are transmitted to the engine module.

In the engine module, fuel consumption is calculated by reading the engine operating point on the fuel consumption map. $\mathrm{CO}_{2}$ emissions are calculated from fuel consumption based on carbon balance. For diesel fuel, the carbon balance method is shown in the equation below (MOTIE, 2015).

Fuel efficiency $\left[\mathrm{km} \mathrm{L}^{-1}\right]=\left(C W F_{\text {diesel }} \times D_{\text {fuel }}\left[\mathrm{g} \mathrm{L}^{-1}\right]\right) /$ $\left(C W F_{\mathrm{HC}} \times \mathrm{HC}\left[\mathrm{g} \mathrm{km}^{-1}\right]+C W F_{\mathrm{CO}} \times C O\left[\mathrm{~g} \mathrm{~km}^{-1}\right]+C W F_{\mathrm{CO}_{2}}\right.$ $\left.\times \mathrm{CO}_{2}\left[\mathrm{~g} \mathrm{~km}^{-1}\right]\right)$

where $C W F_{\text {diesel }}$ is carbon weight fraction of diesel (-), $D_{\text {fuel }}$ is fuel density $\left(\mathrm{g} \mathrm{L}^{-1}\right), C W F_{\mathrm{HC}}$ is carbon weight fraction of hydrocarbon (-), $\mathrm{HC}$ is hydrocarbon emission $\left(\mathrm{g} \mathrm{km}^{-1}\right)$, $C W F_{\mathrm{CO}}$ is carbon weight fraction of carbon monoxide (-), $\mathrm{CO}$ is carbon monoxide emission $\left(\mathrm{g} \mathrm{km}^{-1}\right), C W F_{\mathrm{CO}_{2}}$ is carbon weight fraction of carbon dioxide $(-)$, and $\mathrm{CO}_{2}$ is carbon dioxide emission $\left(\mathrm{g} \mathrm{km}^{-1}\right)$.

In this paper, hydrocarbon emissions and carbon monoxide emissions were not considered. For diesel, the $\mathrm{CO}_{2}$ conversion coefficient is $2593 \mathrm{~g} \mathrm{CO}_{2}$ per $1 \mathrm{~L}$ diesel, which is determined from Eq. (2). Although carbon balance standards for $\mathrm{CO}_{2}$ emissions of natural gas have not been established in Korea, Eq. (2) was applied to determine the $\mathrm{CO}_{2}$ conversion coefficient of $\mathrm{CNG}$ by considering the fuel properties of $\mathrm{CNG}$. The carbon balance method and natural gas properties were used to calculate the $\mathrm{CO}_{2}$ conversion coefficient of CNG, which is $2029 \mathrm{~g} \mathrm{CO}_{2}$ per $1 \mathrm{~m}^{3} \mathrm{CNG}$ at $20^{\circ} \mathrm{C}$ (Han et al., 2017). In addition, energy efficiency was calculated based on the lower heating value (LHV). The unit of energy efficiency is $\mathrm{km} \mathrm{GJ}^{-1}$. The LHV of diesel and CNG is based on Korean energy calorific value conversion standards (MOTIE, 2017). All the fuel properties used in this paper are shown in Table 2.

Before we calculated the GHG emissions by using simulation model, the accuracy of the simulation model was analyzed. Chassis dynamometer test were performed to compare the measured results with simulation results. Considering the vehicle statistics publication (KAMA, 2018), 3 CNG HDVs that most sold in Korea were selected for chassis dynamometer test. The specifications of test vehicles are shown in Table 3. These vehicles were tested in the heavy-duty chassis dynamometer shown in Fig. 4. Vehicle exhaust gases such as $\mathrm{THC}, \mathrm{CH}_{4}, \mathrm{NO}_{x}$ and $\mathrm{CO}_{2}$ were measured in a gaseous emission analyzer through a CVS system. In addition to exhaust emissions, an OBD scanner was used to acquire vehicle operating variables such as engine speed, engine torque and fuel consumption. After the validation of simulation model, we calculate the GHG emissions from heavy-duty NGVs in Korea.

In this paper, $40 \mathrm{CNG}$ city bus models were used for simulation calculation. Simulation results of CNG HDVs were used to estimate the total amount of $\mathrm{CO}_{2}$ emissions for 1 year, as shown in Eq. (3):

Total GHG emission $\left[\mathrm{g}\right.$ year $\left.{ }^{-1}\right]=\sum E_{G H G}\left[\mathrm{~g} \mathrm{~km}^{-1}\right] \times N \times$ VMT $\left[\mathrm{km}\right.$ year $\left.^{-1}\right]$

where Total GHG emission is the GHG emissions from CNG HDVs for 1 year $\left(\mathrm{g}\right.$ year $\left.{ }^{-1}\right), E_{G H G}$ is the GHG simulation result $\left(\mathrm{g} \mathrm{km}^{-1}\right), N$ is the number of CNG HDVs sharing the same $E_{G H G}$, and $V M T$ is the vehicle miles travelled for 1 year $\left(\mathrm{km} \mathrm{year}^{-1}\right)$.

\section{RESULT AND DISCUSSION}

\section{Model Validation}

In this paper, simulation results were validated by comparing with chassis dynamometer test results. For comparative analysis, engine speed, engine torque and $\mathrm{CO}_{2}$ emissions of each test result were compared. K-WHVC and WHVC driving cycles were used for both chassis dynamometer tests and simulation calculations.

Fig. 5(a) shows the measured and calculated engine speed of Vehicle 1 in the K-WHVC driving cycle. The blue line is the engine speed calculated by using the simulation model. The red line is the engine speed measured by the chassis dynamometer test. During K-WHVC driving, engine speed is predicted well by the simulation model, with good agreement with the chassis dynamometer test results. 
Table 2. Diesel and CNG fuel properties.

\begin{tabular}{lll}
\hline Items & Diesel & $\mathrm{CNG}\left(20^{\circ} \mathrm{C}, 1 \mathrm{~atm}\right)$ \\
\hline Lower heating value & $35.2 \mathrm{MJ} \mathrm{L}^{-1}$ & $36.19 \mathrm{MJ} \mathrm{m}^{-3}$ \\
Carbon weight fraction & $83.7 \%$ & $75.6 \%$ \\
Density & $0.845 \mathrm{~kg} \mathrm{~L}^{-1}$ & $0.732 \mathrm{~kg} \mathrm{~m}^{-3}$ \\
$\mathrm{CO}_{2}$ conversion factor & $2593 \mathrm{~g} \mathrm{CO}_{2} \mathrm{~L}^{-1}$ & $2029 \mathrm{~g} \mathrm{CO}_{2} \mathrm{~m}^{-3}$ \\
\hline
\end{tabular}

Table 3. Test vehicle specifications.

\begin{tabular}{llllllll}
\hline No. & Engine & $\begin{array}{l}\text { Maximum } \\
\text { power }\end{array}$ & $\begin{array}{l}\text { Length/width/height } \\
(\mathrm{m})\end{array}$ & Weight & Transmission & $\begin{array}{l}\text { Passenger } \\
\text { capacity }\end{array}$ & $\begin{array}{l}\text { Model } \\
\text { year }\end{array}$ \\
\hline 1 & 11.6 L CNG & 290 PS & $11 / 2.5 / 3.2$ & 13.1 tons & Manual 5 & 54 & 2018 \\
2 & 11.1 L CNG & 290 PS & $11 / 2.5 / 3.2$ & 12.7 tons & Manual 5 & 50 & 2008 \\
3 & 6.79 L CNG & 240 PS & $9.1 / 2.5 / 3.2$ & 10.3 tons & Manual 5 & 25 & 2014 \\
\hline
\end{tabular}

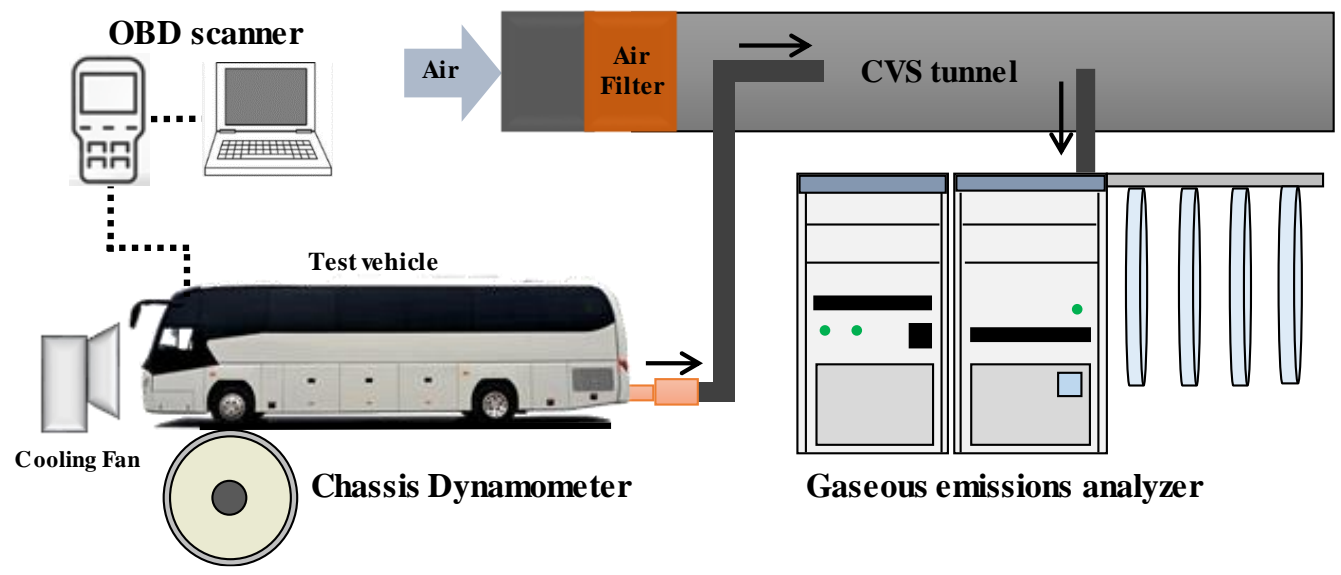

Fig. 4. Schematic diagram of chassis dynamometer test system.

Fig. 5(b) shows engine torque results of Vehicle 1 in the $\mathrm{K}-\mathrm{WHVC}$ driving cycle. In addition to the engine speed comparison results, the engine torque results were similar between the chassis dynamometer test results and the simulation results. Although there is some error, especially at low engine torque, it is negligible in terms of the overall accuracy.

Fig. 5(c) presents $\mathrm{CO}_{2}$ emissions at each time step of Vehicle 1 during the K-WHVC driving cycle. In the chassis dynamometer test, $\mathrm{CO}_{2}$ emissions from the vehicle are measured directly in the exhaust gas analyzer. In the simulation model, $\mathrm{CO}_{2}$ emissions are converted by applying a $\mathrm{CO}_{2}$ emission factor to fuel consumption. Fuel consumption is calculated by reading engine operating points on a fuel consumption map at each time step. Therefore, with an accurate engine operating point, simulation model calculates accurate fuel consumption from the fuel consumption map. Fig. 5(c) show the similar trends for $\mathrm{CO}_{2}$ emissions in the simulation result and chassis dynamometer result.

Fig. 6 shows the $1 \mathrm{~Hz}$ engine operating point of Vehicle 1 for the chassis dynamometer test results and simulation results. Red and blue points represent engine operating points in the $\mathrm{K}-\mathrm{WHVC}$ test. The black line indicates the maximum engine torque. The distribution of operating points is quite similar between the chassis dynamometer test results and simulation results. Through the validation analysis shown in Figs. 5 and
6 , it can be concluded that the simulation model is a good representation of the driving characteristics of a real vehicle.

Fig. 7 shows $\mathrm{CO}_{2}$ emission results of the K-WHVC and WHVC driving cycles. Vehicle 1 was tested in both the KWHVC and WHVC driving cycles, and Vehicle 2 and Vehicle 3 were tested in the WHVC driving cycle only.

The average errors between the simulation and chassis dynamometer test are as follows: Vehicle 1 in K-WHVC, $0.17 \%$; Vehicle 1 in WHVC, $3.75 \%$; Vehicle 2 in WHVC, $5.08 \%$; and Vehicle 3 in WHVC, $0.56 \%$. All of the comparison results show that the simulation model accurately predicts the $\mathrm{CO}_{2}$ emissions from the real vehicle test. From the results of Vehicle 1, the $\mathrm{CO}_{2}$ emissions of the WHVC driving cycle are higher than those of the K-WHVC driving cycle. The K-WHVC driving cycle was developed based on the WHVC driving cycle by smoothing the acceleration gradient to increase vehicle traceability (Park et al., 2013). For this reason, it is a reasonable result that $\mathrm{K}-\mathrm{WHVC}$ driving results are more fuel-efficient than WHVC driving results.

Fig. 8 shows $\mathrm{CO}_{2}$ emission maps at the same scale, which are converted from the $\mathrm{CNG}$ engine and diesel engine fuel consumption maps using the $\mathrm{CO}_{2}$ conversion factors in Table 2. Fig. 8(a) is a CNG engine emission map for Vehicle 1. The engine displacement of the $\mathrm{CNG}$ engine is $11.6 \mathrm{~L}$ and the engine's maximum power is 290 PS. Fig. 8(b) is a diesel engine emission map; its displacement is $10 \mathrm{~L}$ and the engine's 
maximum power is $310 \mathrm{PS}$. Although the specifications of these two engines are slightly different, these two engines are used in same vehicle model. The engine displacement of the $\mathrm{CNG}$ engine is larger than that of the diesel engine. However, the maximum power and operation range of the CNG engine are smaller than those of the diesel engine.
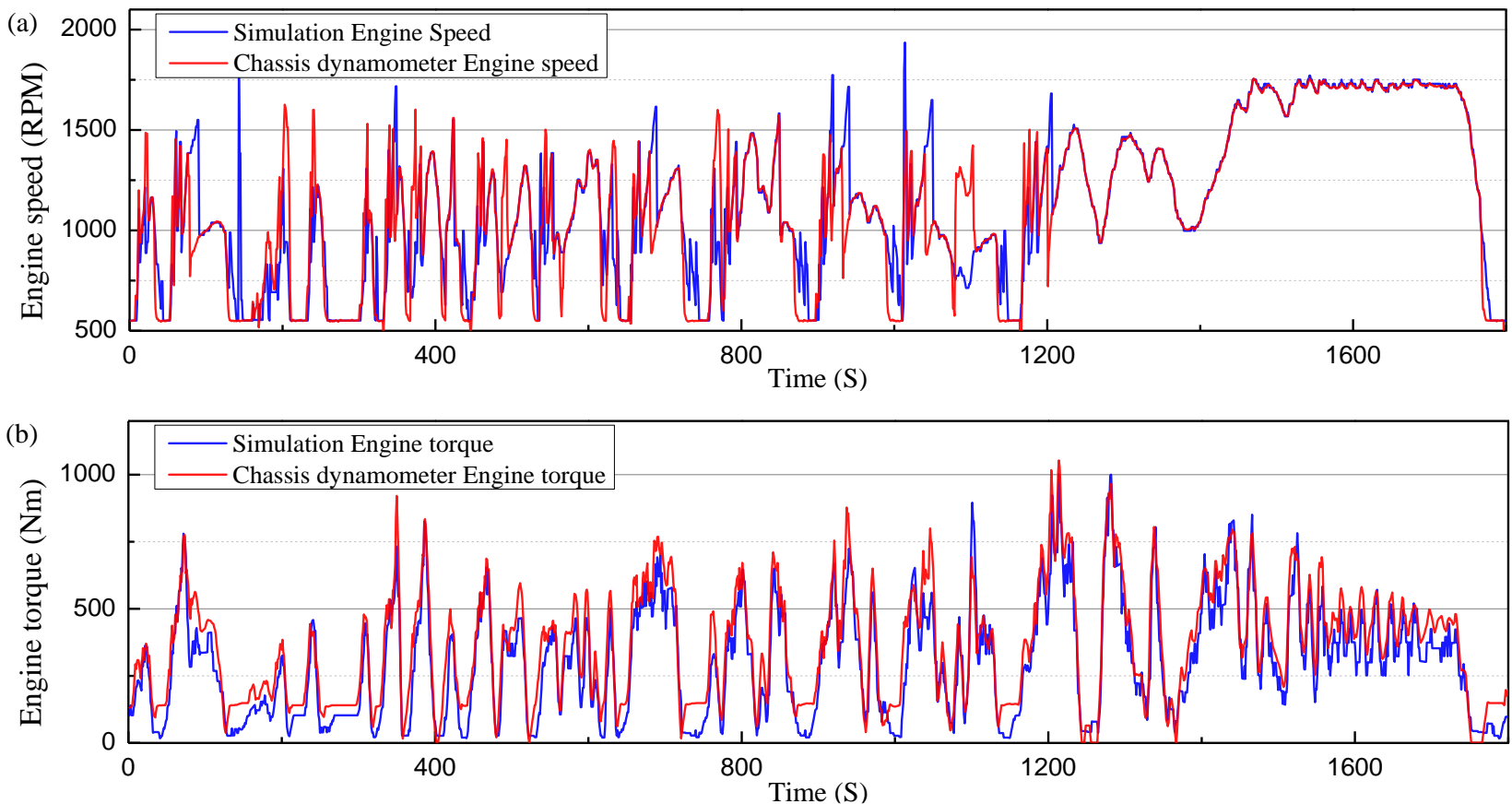

(c)

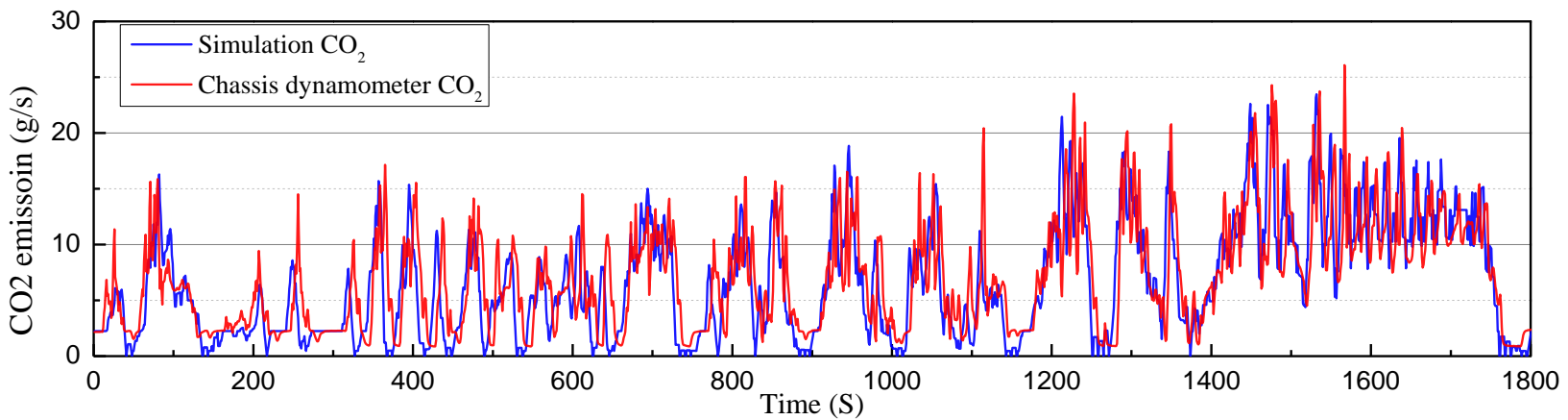

Fig. 5. K-WHVC chassis dynamometer test and simulation results of Vehicle 1: (a) engine speed, (b) engine torque, (c) $\mathrm{CO}_{2}$ emission.

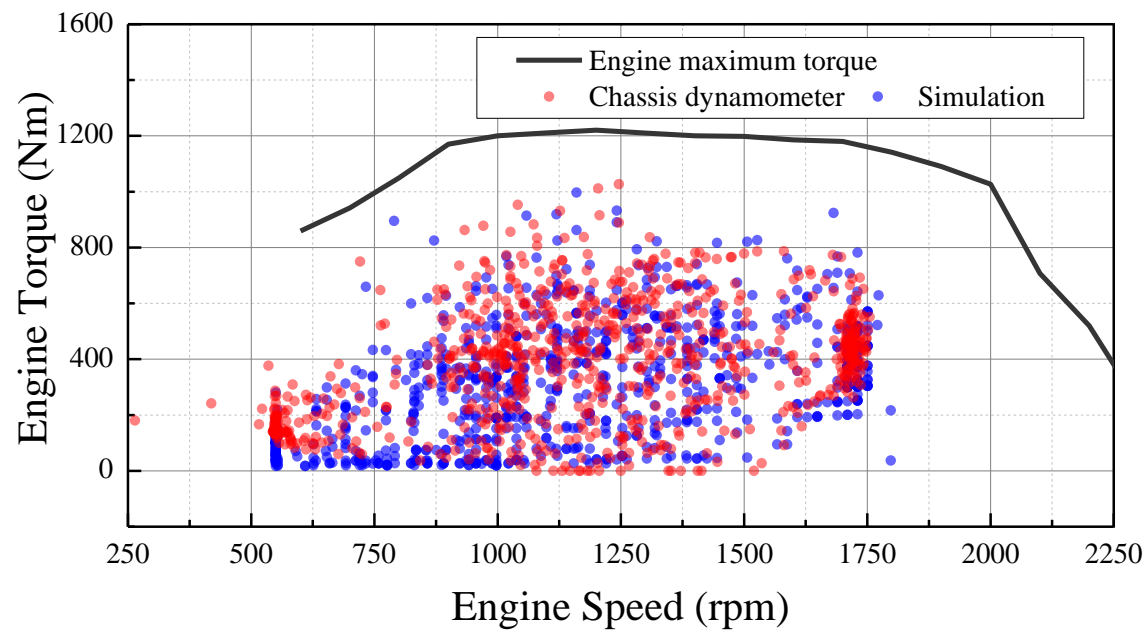

Fig. 6. K-WHVC engine operating point comparison of Vehicle 1. 


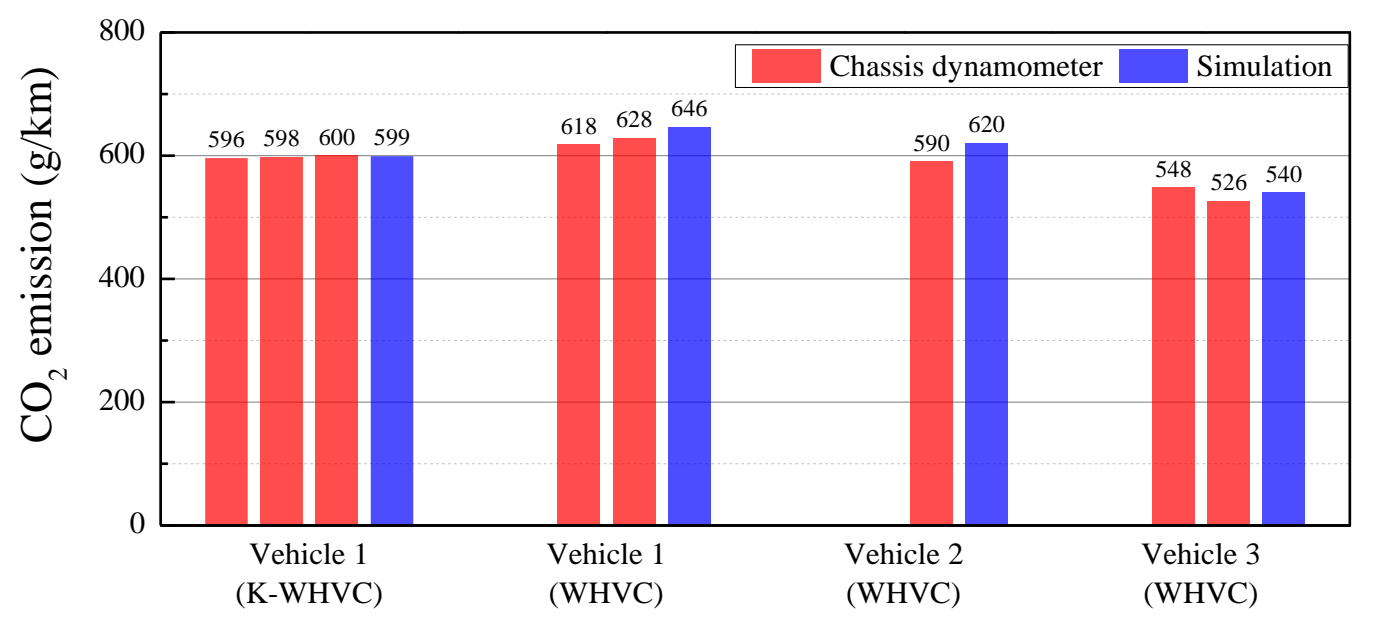

Fig. 7. $\mathrm{CO}_{2}$ emission result of chassis dynamometer test and simulation.
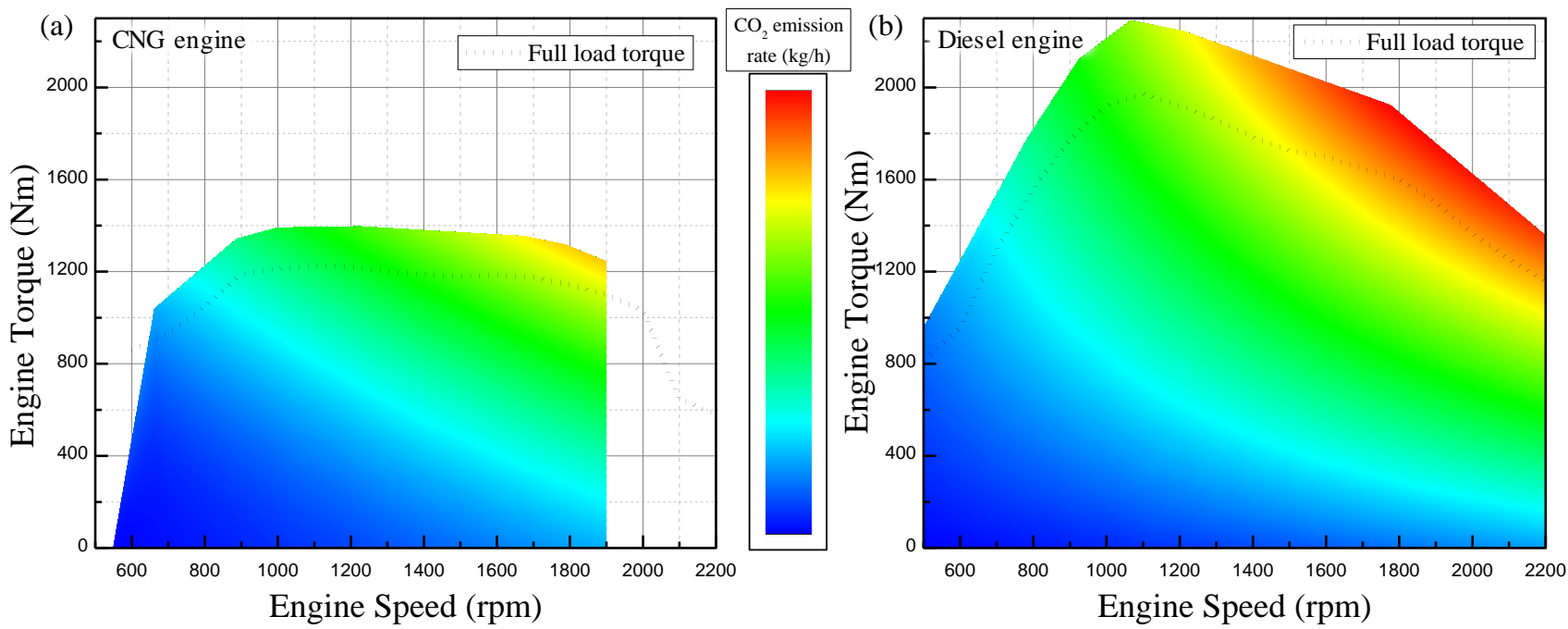

Fig. 8. Engine $\mathrm{CO}_{2}$ emission map: (a) CNG engine of Vehicle 1 (11.6 L, 290 PS), (b) diesel engine (10 L, 310 PS).

In addition to $\mathrm{CO}_{2}$ emissions, $\mathrm{CH}_{4}$ emissions were measured in the chassis dynamometer test. $\mathrm{CH}_{4}$ is the prime constituent of natural gas, and the global warming potential of $\mathrm{CH}_{4}$ is 28 times greater than that of $\mathrm{CO}_{2}$, according to the IPCC Fifth Assessment Report (IPCC, 2014). Because of the high global warming potential of $\mathrm{CH}_{4}$, even a small amount of $\mathrm{CH}_{4}$ emissions can cause a significant greenhouse effect (Rajab et al., 2012). To better consider the global warming effect of $\mathrm{CH}_{4}, \mathrm{CO}_{2}$-equivalent $\mathrm{CH}_{4}$ emissions, which is multiplied $\mathrm{CH}_{4}$ emissions by the global warming potential of 28 , are widely used. Fig. 9 shows the measured $\mathrm{CH}_{4}$ emissions of Vehicle 1 in the K-WHVC chassis dynamometer test. The average $\mathrm{CO}_{2}$-equivalent $\mathrm{CH}_{4}$ emissions are $8.76 \mathrm{~g} \mathrm{~km}^{-1}$, which is $1.47 \%$ of the average $\mathrm{CO}_{2}$ emission results. In this paper, an average value of $\mathrm{CO}_{2}$-equivalent $\mathrm{CH}_{4}$ emissions $\left(8.76 \mathrm{~g} \mathrm{~km}^{-1}\right)$ is added to $\mathrm{CO}_{2}$ simulation results to consider the $\mathrm{GHG}$ effect of $\mathrm{CH}_{4}$.

\section{Simulation Results: GHG Emissions from Heavy-duty NGVS}

Fig. 10 shows the simulation results for CNG HDVs and diesel HDVs. These results were calculated in the K-WHVC driving cycle at half-loaded conditions. Red points are $\mathrm{CO}_{2}$ emissions of diesel HDVs and blue points are $\mathrm{CO}_{2}$ emissions of $\mathrm{CNG}$ HDVs. $\mathrm{CO}_{2}$-equivalent $\mathrm{CH}_{4}$ emissions were considered in the CNG HDV results. Most of the CNG HDV data points are distributed over slightly lower values than the diesel HDV data points. This tendency shows that $\mathrm{CNG}$ HDVs are more environmentally friendly than diesel vehicles in terms of GHG emissions. The weight range of CNG HDVs is narrower than weight range of diesel HDVs because most CNG HDVs are used for buses weighing less than 15 tons.

Table 4 show the average $\mathrm{CO}_{2}$ emission results by vehicle weight. All of these values are averaged simulation results of diesel HDVs and CNG HDVs. CNG results are presented in two ways: $\mathrm{CO}_{2}$-only emission and $\mathrm{CO}_{2}$-equivalent emission considering GHG effect of $\mathrm{CH}_{4}$. To consider the GHG effect of $\mathrm{CH}_{4}$, the average value of the $\mathrm{CH}_{4}$ emission result ( $8.76 \mathrm{~g} \mathrm{~km}^{-1}, \mathrm{CO}_{2}$-equivalent), which was measured in the chassis dynamometer test, was added to each simulation result. $\mathrm{CO}_{2}$ emission results are classified into four groups by vehicle weight. The difference between diesel HDV 


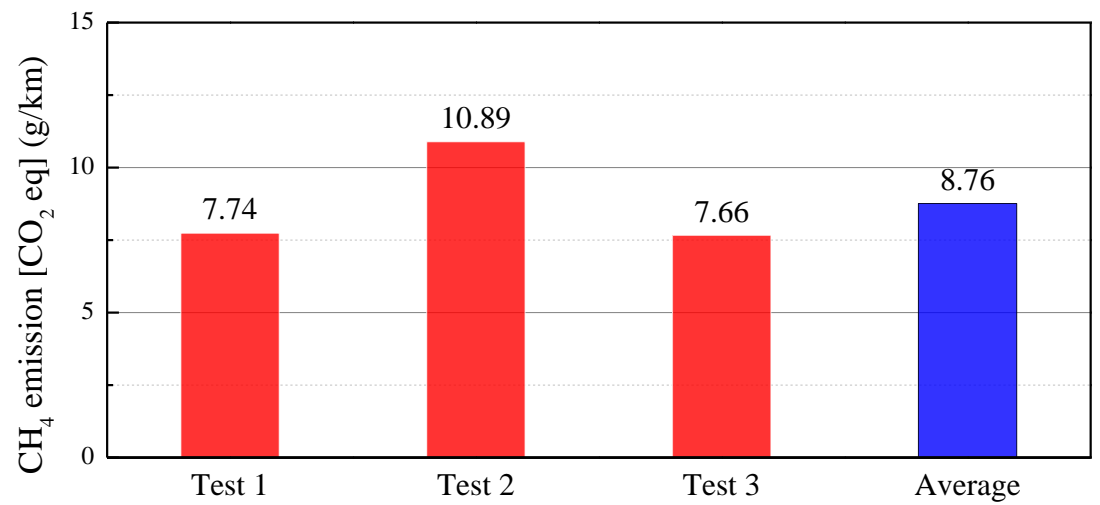

Fig. 9. $\mathrm{CO}_{2}$-equivalent $\mathrm{CH}_{4}$ emissions of Vehicle 1 chassis dynamometer test.

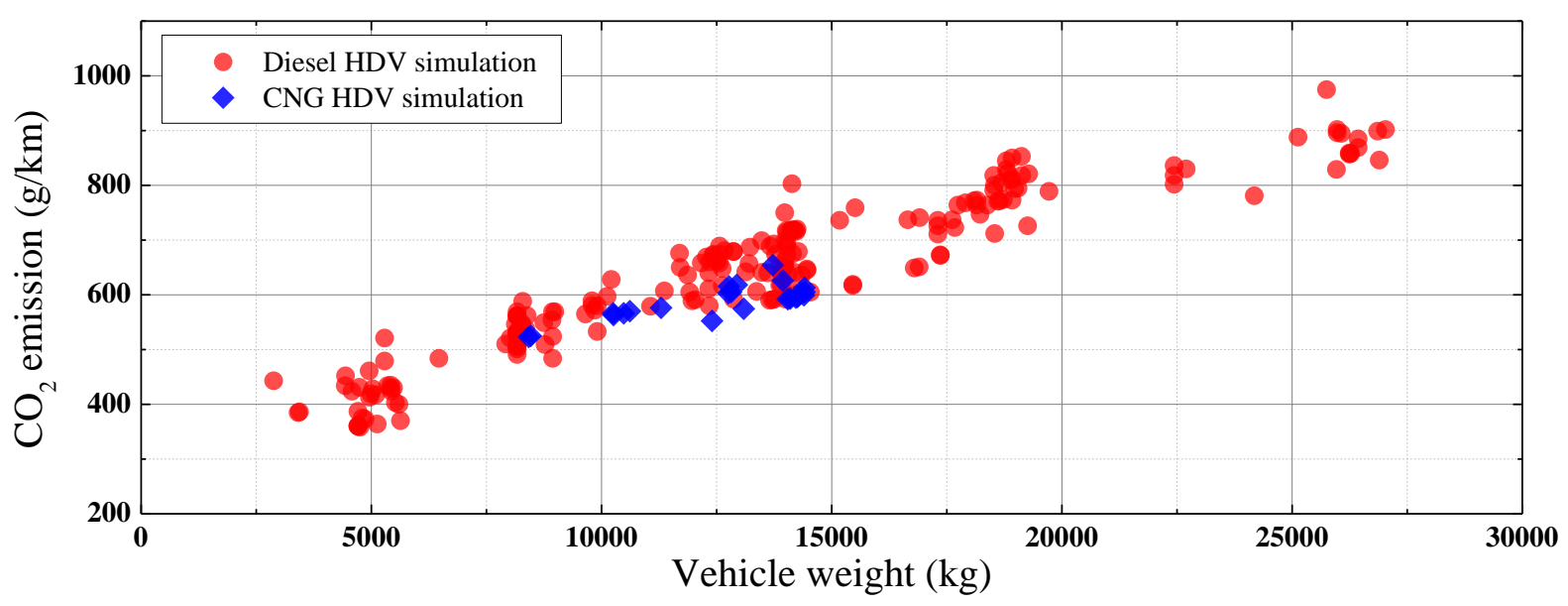

Fig. 10. CNG heavy-duty vehicle simulation results.

Table 4. Average $\mathrm{CO}_{2}$ emissions by vehicle weight.

\begin{tabular}{llll}
\hline \multirow{2}{*}{ Weight range } & \multicolumn{3}{c}{ Average $\mathrm{CO}_{2}$ emissions $\left(\mathrm{g} \mathrm{km}^{-1}, \mathrm{CO}_{2}\right.$-equivalent $)$} \\
\cline { 2 - 4 } & Diesel & $\mathrm{CNG}$ & $\mathrm{CNG}\left(\mathrm{CH}_{4}\right.$ considered $)$ \\
\hline $8-9$ tons & 536 & 522 & 531 \\
$10-12$ tons & 621 & 567 & 576 \\
$12-13$ tons & 650 & 600 & 609 \\
$13-15$ tons & 665 & 611 & 620 \\
\hline
\end{tabular}

emissions and CNG HDV emissions is smallest in the 89 ton weight group. In this group, CNG HDV emissions are $2.6 \%$ lower than diesel HDVs. There is no significant difference in emissions between CNG HDVs and diesel HDVs when considering the GHG effect of $\mathrm{CH}_{4}$. However, the difference of $\mathrm{CO}_{2}$ emissions is much higher in other weight groups. In other weight groups excluding 8-9 tons, average $\mathrm{CO}_{2}$ emissions of CNG HDVs are 6-8\% lower than that of diesel HDVs. In Korea, $89 \%$ of CNG HDVs are heavier than 10 tons (MOLIT, 2018). Considering vehicle distribution of Korean $\mathrm{CNG} \mathrm{HDV}$, the total average $\mathrm{CO}_{2}$ emissions of CNG HDVs is $7.7 \%$ lower than those of diesel HDVs. Considering the GHG effect of $\mathrm{CH}_{4}$, the average $\mathrm{CO}_{2}$-equivalent emission of $\mathrm{CNG}$ HDVs is $6.3 \%$ lower than that of diesel HDVs.

Using simulation result with statistical data such as vehicle registration statistics (KAMA, 2018; MOLIT, 2018) and vehicle miles travelled statistics (TS, 2018), we calculated total $\mathrm{CO}_{2}$ emissions from $\mathrm{CNG} \mathrm{HDV}$ for 1 year using Eq. (3). $\mathrm{CO}_{2}$-equivalent $\mathrm{CH}_{4}$ emissions were considered in this calculation.

Fig. 11 shows the total $\mathrm{CO}_{2}$ emissions from $\mathrm{HDV}$ s in Korea. 1.66 million tons of $\mathrm{CO}_{2}$-equivalent $\mathrm{GHGs}$ are emitted from CNG HDVs. This is $6.75 \%$ of total GHG emissions from HDVs in Korea. The annual GHG emissions of HDVs in Korea are 24.6 million tons, including emissions from both CNG and diesel HDVs. Since most HDVs in Korea use diesel and CNG as fuels, other types of fuel are not considered in Fig. 11.

In this paper, we found that the $\mathrm{CO}_{2}$-equivalent $\mathrm{GHG}$ emissions of CNG HDVs are $6.3 \%$ lower than those of diesel HDVs. Therefore, replacing diesel HDVs with CNG HDVs has GHG reduction effect and total 26,651 CNG HDVs are used in Korea. The GHG reduction effects of 26,651 CNG HDVs are total 104.7 thousand tons per year compared to 


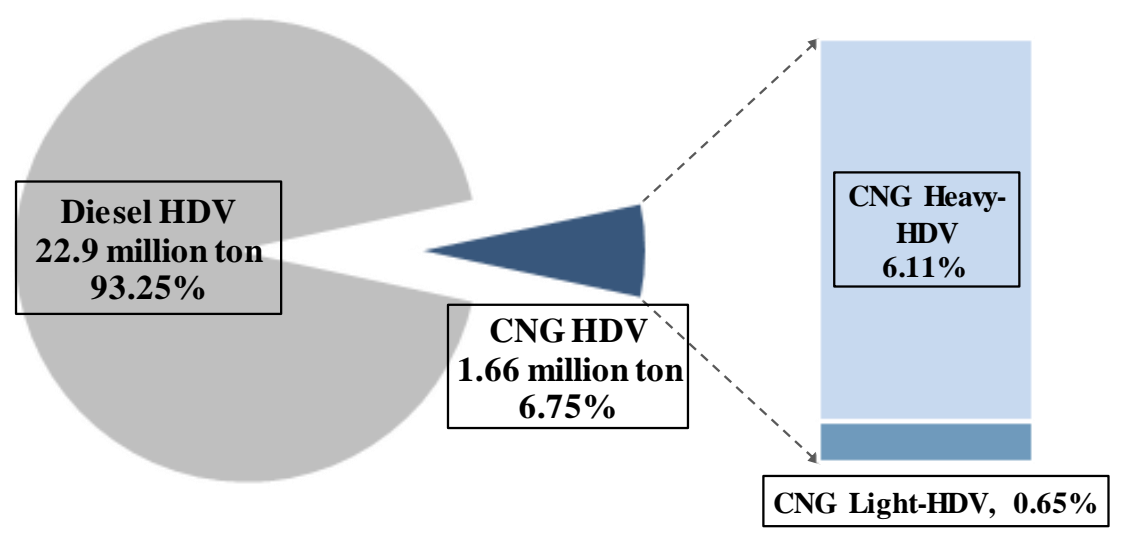

Fig. 11. Total greenhouse gas emissions from CNG heavy-duty vehicle for 1 year.

when CNG HDVs had not been introduced. The GHG reduction effect of $1 \mathrm{CNG}$ HDV is 39.3 tons per year. These results show that CNG HDVs have a considerable GHG reduction effect and introducing more $\mathrm{CNG}$ HDVs can be an effective solution for GHG reduction in the transportation sector.

\section{Simulation Results: Energy Efficiency of Heavy-duty NGVs}

Fig. 12 shows energy efficiency based on the LHV of diesel and CNG. The fuel properties in Table 2 were used to calculate energy efficiency. In contrast to GHG emissions, the energy efficiency of CNG HDVs is lower than that of diesel HDVs. The thermal efficiency of CNG engines using stoichiometric combustion is lower than diesel engines due to fuel properties, combustion characteristics, low volumetric efficiency and pumping losses (Cho and He, 2007; Semin, 2008; Korakianitis et al., 2011), and vast majority of Korean CNG HDVs use stoichiometric combustion. For these reason the energy efficiency of CNG HDVs are lower than of diesel HDVs.

Fig. 13 shows simulation results of fuel efficiency, which is widely used standard for vehicle performance. However, different units were used for the fuel efficiency of $\mathrm{CNG}$ HDVs and diesel HDVs. As CNG is gaseous fuel, $\mathrm{km} \mathrm{m}^{-3}$ is used as standard unit of fuel efficiency. On the other hands, since diesel is liquid fuel, $\mathrm{km} \mathrm{L}^{-1}$ is used as standard unit. Although it is difficult to directly compare fuel efficiency between CNG HDVs and diesel HDVs, the trend of the data points in Fig. 13 is very similar to that of the energy efficiency data points in Fig. 12.

\section{CONCLUSION}

In this study, we estimated the total GHG emissions and energy efficiency for CNG HDVs in Korea. Our major conclusions are summarized below:

1) A simulation model and statistical data were used to calculate the GHG emission of CNG HDVs on a macroscopic level. The annual GHG emissions from these vehicles equalled 1.66 million tons, accounting for $6.75 \%$ of the total GHG emissions from HDVs in Koreaa relatively high percentage compared to the number of CNG HDVs, which comprise only $2.4 \%$ of the total HDV population. However, most CNG HDVs are used in public transit, which exhibits much higher average vehicle mileages than other transportation sectors.

2) CNG HDVs produce $6.3 \%$ less emissions (in $\mathrm{g} \mathrm{km}^{-1}$ ) than diesel HDVs of a similar weight. On average, $1 \mathrm{CNG}$ HDV emits 39.3 tons less GHG than 1 diesel HDV per

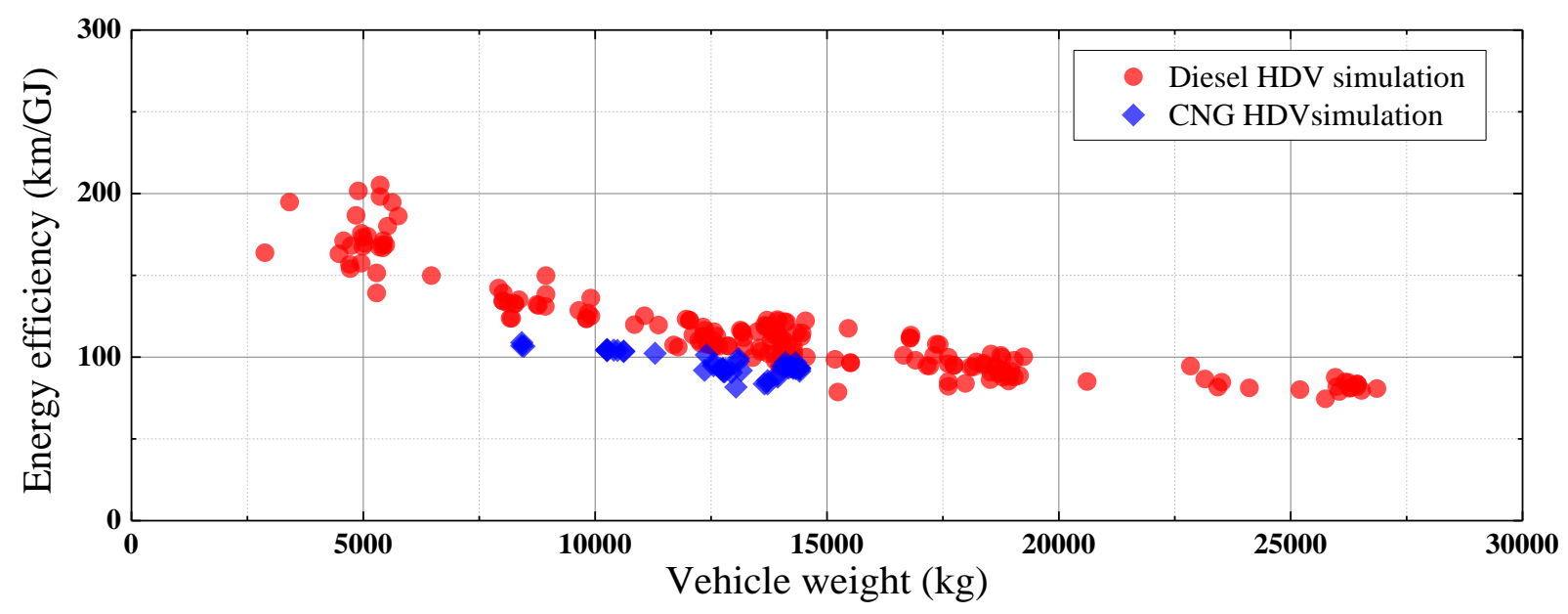

Fig. 12. Energy efficiency of CNG and diesel heavy-duty vehicles based on lower heating value of fuel. 


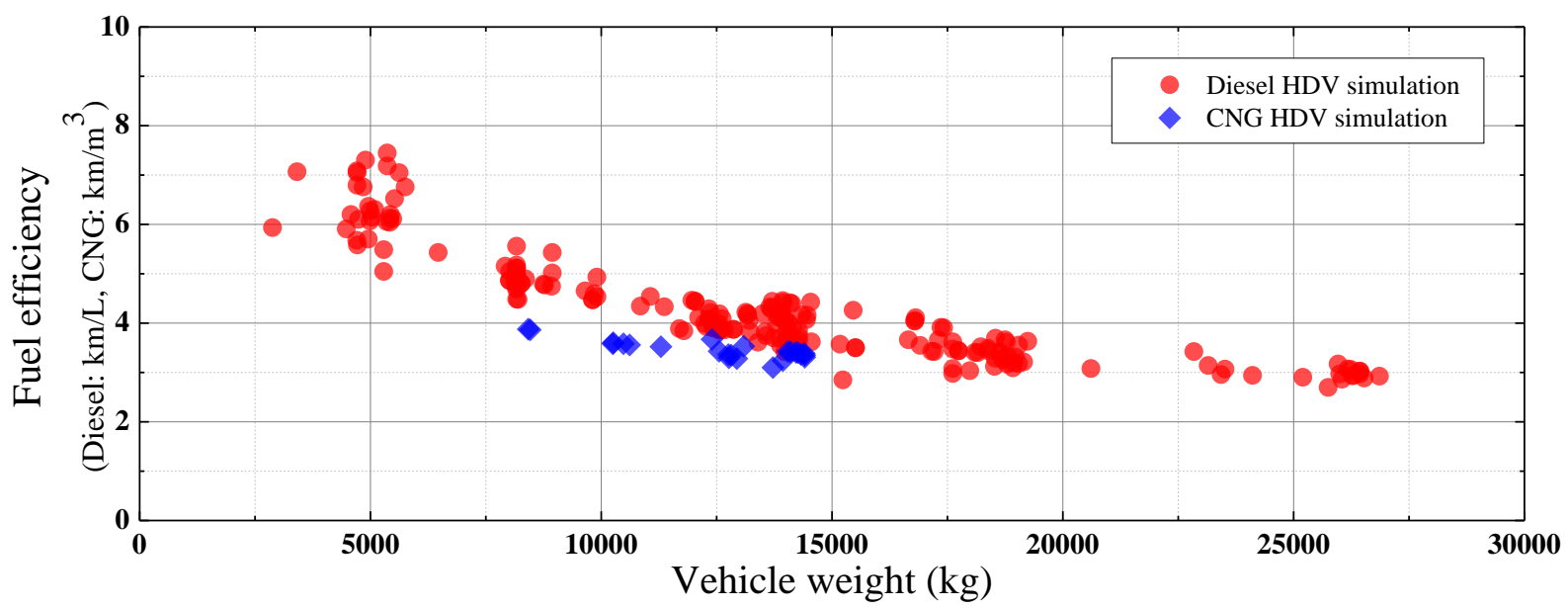

Fig. 13. Fuel efficiency of $\mathrm{CNG}\left(\mathrm{km} \mathrm{m}^{-3}\right)$ and diesel $\left(\mathrm{km} \mathrm{L}^{-1}\right)$ heavy-duty vehicles.

year. In Korea, the use of 26,651 CNG HDVs has resulted in a total decrease in GHG of 104.7 thousand tons per year. Hence, replacing diesel vehicles with NGVs effectively reduces these emissions.

3) Although CNG HDVs exhibit superior efficiency in reducing emissions, based onGHG emissions efficiency of CNG HDVs is superior to that of diesel HDVs, but the LHV, diesel HDVs display higher energy efficiency due to differences in the fuel properties and combustion characteristics. However, as global concern over GHG emissions continues to rise, reduced emission has become more important than LHV-based energy efficiency as a performance criterion for vehicles.

4) Another source of GHG was upstream methane leakage from the natural gas system, although tank-to-wheel emission was examined as a candidate. Future work should thus address the total upstream GHG emission in Korea. In addition to the reduction in GHG, the advantages of NGVs include the wide availability of natural gas and the vehicles' compatibility with conventional engines, as well as eco-friendliness and economical viability. Considering these factors altogether, heavy-duty NGVs serve as a beneficial alternative to diesel HDVs.

\section{ACKNOWLEDGMENTS}

This work was supported by "Human Resources Program in Energy Technology" of the Korea Institute of Energy Technology Evaluation and Planning (KETEP), granted financial resource from the Ministry of Trade, Industry \& Energy, Republic of Korea (No. 20184010201710).

\section{REFERENCES}

Agarwal, A.K., Bothra, P. and Shukla, P.C. (2015). Particulate characterization of $\mathrm{CNG}$ fuelled public transport vehicles at traffic junctions. Aerosol Air Qual Res. 15: 2168-2174.

Cho, H.M. and He, B.Q. (2007). Spark ignition natural gas engines-A review. Energy Convers. Manage. 48: 608618.
Engerer, H. and Horn, M. (2010). Natural gas vehicles: An option for Europe. Energy Policy. 38: 1017-1029.

Graham, L.A., Rideout, G., Rosenblatt, D. and Hendren, J. (2008). Greenhouse gas emissions from heavy-duty vehicles. Atmos Environ. 42: 4665-4681.

Han, J., Kim, Y. and Lee, Y. (2017). Fuel consumption and $\mathrm{CO}_{2}$ characteristics of HCNG bus. J. Korean Inst. Gas 21: 20-25.

IPCC (2014). Climate Change 2014: Synthesis Report. Contribution of Working Groups I, II and III to the Fifth Assessment Report of the Intergovernmental Panel on Climate Change, Core Writing Team, Pachauri, R.K. and Meyer, L.A. (Eds.), IPCC, Geneva, Switzerland, 151 pp.

Khan, M.I., Yasmin, T. and Shakoor, A. (2015). Technical overview of compressed natural gas (CNG) as a transportation fuel. Renewable Sustainable Energy Rev. 51: 785-797.

Korakianitis, T., Namasivayam, A.M. and Crookes, R.J. (2011). Natural-gas fueled spark-ignition (SI) and compression-ignition (CI) engine performance and emissions. Prog. Energy Combust. Sci. 37: 89-112.

Korea Automobile Manufacturers Association (KAMA) (2018). Automobile registration statistics in Korea. Korea Automobile Manufacturers Association, Koren.

Korea Transportation Safety Authority (TS) (2018). 2017 Korea vehicle mileage statistics. http://www.kotsa.or.kr/ tsk/rck/InqDetPTRTrafficSafety.do?ctgCd=-1\&searchCt $\mathrm{gCd}=+\&$ bbsSn=5421\&pageIndex $=1+\&$ searchCnd=\&sea rchWrd=, Last Access: 14 April 2020.

Lajevardi, S.M., Axsen, J. and Crawford, C. (2018). Examining the role of natural gas and advanced vehicle technologies in mitigating $\mathrm{CO}_{2}$ emissions of heavy-duty trucks: Modeling prototypical British Columbia routes with road grades. Transp. Res. D 62: 186-211.

Mock, P. (2019). European Vehicle Market Statistics: Pocketbook 2018/9. International Council on Clean Transportation (ICCT), Berlin.

Park, J., Lee, J.H. and Lee, J. (2013). Development of driving cycle for $\mathrm{CO}_{2}$ emission test of heavy-duty vehicles. SAE Technical Paper 2013-01-2520.

Rajab, J.M., Matjafri, M.Z. and Lim, H.S. (2012). Methane 
interannual distribution over Peninsular Malaysia from atmospheric infrared sounder data: 2003-2009. Aerosol Air Qual Res. 12: 1459-1466.

Rodríguez, F. (2018). Fuel consumption simulation of HDVs in the EU: Comparisons and limitations. International Council on Clean Transportation (ICCT), Berlin.

Semin, R.A.B. (2008). A technical review of compressed natural gas as an alternative fuel for internal combustion engines. Am. J. Eng. Appl. Sci. 1: 302-311.

Seo, J., Kim, H. and Park, S. (2018). Estimation of $\mathrm{CO}_{2}$ emissions from heavy-duty vehicles in Korea and potential for reduction based on scenario analysis. Sci. Total Environ. 636: 1192-1201.

Sharpe, B. and Muncrief, R. (2015). Literature review: RealWorld fuel consumption of heavy-duty vehicles in the United States, China, and the European Union. International Council on Clean Transportation (ICCT), Washington DC.

South Korean Minister of Land, Infrastructure and Transport (MOLIT) (2018). 2017 handbook of bus statistics. Minister of Land, Infrastructure and Transport, Korea.

South Korean Minister of Trade, Industry and Energy (MOTIE) (2017). Korean energy calorific value conversion standard. Minister of Trade, Industry and Energy, Korea.
South Korean Ministry of Environment (ME) (2018). 2030 greenhouse gas reduction roadmap amendment and establishment of emission quota allocation plan for 20182020. Ministry of Environment, Korea.

South Korean MOTIE and MOLIT (2015). Test methods for vehicle energy efficiency, greenhouse gas emissions, and fuel consumption. http://www.motie.go.kr/common/downl oad.do?fid=bbs\&bbs_cd_n $=5 \& b b s \_s e q \_n=62470 \& f i l e \_s$ eq_n=1, Last Access: 14 April 2020.

Thiruvengadam, A., Besch, M., Padmanaban, V., Pradhan, S. and Demirgok, B. (2018). Natural gas vehicles in heavy-duty transportation-A review. Energy Policy 122: 253-259.

Watabe, A., Leaver, J., Ishida, H. and Shafiei, E. (2019). Impact of low emissions vehicles on reducing greenhouse gas emissions in Japan. Energy Policy. 130: 227-242.

Yang, Z. and Bandivadekar, A. (2017). Light-duty vehicle greenhouse gas and fuel economy standards. International Council on Clean Transportation (ICCT), Washington DC.

Received for review, October 29, 2019

Revised, January 18, 2020

Accepted, February 27, 2020 